\title{
Experiencias de la diversidad en las fronteras del yo y la antropología
}

Experiences of diversity at the frontiers of the self and anthropology

RESUMEN

La experiencia consciente de la diversidad es una manera privilegiada de hacer frente a las más grandes contradicciones de lo humano y a los desafíos de la vida en compañía de otros. Este es un relato amable del nacimiento de esta idea antropológica que solamente fue posible gracias a la vivencia antropológica. Es decir, en aquel momento en que la antropología deja de ser un oficio y se entierra en los oídos, las manos, los ojos y la boca. Las ideas importantes suelen tardar en concretarse, es difícil aprehenderlas, domesticarlas. Este relato es una oportunidad de capturar la idea que vuela entre mi experiencia diaria, mi imaginación y mi memoria. Esta idea se ha convertido en la razón implícita y silenciosa que me empuja todos los días a levantarme a luchar en y desde mi oficio. Mi narración pretende restituir algunos momentos en los que esta idea ha florecido y se ha expresado de manera a veces sutil y otras veces furiosa.

Palabras clave: antropología, diversidad, "fronteras del yo".
Sofía LARA-LARGO

PhD en Antropología y

Sociología, Universidad

de Paris VII Diderot.

Profesora de la Universidad

Tecnológica de Pereira.

凹 sofia.lara@utp.edu.co

(D) ORCID: 0000-0001-8407-3773

$\checkmark$ Google Scholar 


\begin{abstract}
The conscientious experience of diversity is one of the privileged ways to face the most obvious contradictions of human experience as well as the challenges of life with others. This is a kindhearted narrative of the origin of this anthropological idea, which was possible only thanks to the anthropological experience. That is to say, the precise moment when anthropology is no longer a profession and buries itself in ears, hands, eyes, and mouth. Usually, important ideas take time to develop, they are difficult to apprehend and tame. This account is an opportunity to capture the idea that hovers among my daily experience, my imagination, and my memory. This idea has become the implicit and quiet reason that pushes me every day to fight in and from my profession. My narrative tries to restore some moments in which this idea has flourished and has been expressed subtly sometimes and furiously some other times.
\end{abstract}

Keywords: Anthropology, diversity, "frontiers of the self".

os antropólogos que nos dedicamos a la investigación y a la etnografía aprendemos a pensar la esquiva realidad de una manera singular. Aprendemos a construir problemas que nacen de las genuinas inquietudes y vivencias de otros a quienes consideramos casi siempre ajenos. En algunos momentos del agridulce trasegar en mi oficio, me he sentido abrumada y dudosa. He pensado que quizás debí haber hecho una de las tantas otras cosas que amo hacer. Alguna vez me convencí de que debían existir, al alcance de mi mano, oficios menos dolorosos, extenuantes y exigentes. En los momentos más difíciles de esta carrera -que implica a veces combatir y luchar frente a las envidias, los celos, las intrigas, la competencia intelectual y la tortuosa maquinaria de la "producción" académica, en el sentido más mercantil del término-, me sentí tentada a dar un paso al lado y dedicarme a otra cosa.

En esos momentos reflexioné con atención y contemplé bajo algún árbol y en compañía de algún animal no humano, las opciones que tendría. Pensé en qué haría con las deudas millonarias que había adquirido, basada en mi creencia ciega de que la educación era el único camino. Pensé en qué explicación simple daría a los que me han visto crecer en la antropología, la mayoría de las veces sin entender qué hago, pero convencidos, eso sí, de que seguro es algo importante. Calculé las consecuencias dolorosas del abandono. Abandonar el oficio es en cierta manera abandonarse o dejarse en soledad a sí mismo, sensación incómoda y desesperanzadora. 
Con esta última reflexión me di cuenta de que justamente la antropología hacía mucho había dejado de ser mi oficio: era una manera particular de vivir y acompañar a otros en la vida. Me di cuenta de que no había elección ni ninguna decisión que tomar, porque lo que uno es, en lo más profundo, ya no puede dejar de serlo. Así que me tranquilicé en la impotencia. Me di cuenta de que no había ningún otro camino posible más que seguir viviendo como lo que siempre he sido, una antropóloga.

Así pues, ¿̇cómo nace, madura y se afianza una idea a partir desde esta sensibilidad? ¿Una idea sensible que no tiene otra demostración posible más que la experiencia propia en la que fue concebida? La idea de la que les hablaré apareció ante mí con claridad hace no mucho tiempo. De hecho, fue hace apenas unas pocas semanas.

Debo señalar a modo de preámbulo que mi experiencia como antropóloga me ha llevado a estudiar contextos marcados por la guerra, el destierro, la injusticia, el dolor, la pobreza económica y humana, la catástrofe y la muerte. Pero también siendo colombiana crecí en la guerra, sufrí la injusticia, vi de cerca el dolor de otros, soy una sobreviviente de la pobreza económica y de la catástrofe que vivieron mis ancestros y he sentido pasar la muerte al lado, apenas rozando. La antropología me ha regalado al mismo tiempo la decepción y la esperanza. A veces entiendo con tanta claridad la conducta de la gente, que me lleno de desesperación y de frustración frente al absurdo y la crueldad de lo humano. Luego vuelvo sobre mis propios pasos y me encuentro con las bellas contradicciones inherentes a este animal sensible, frágil y emotivo que somos y que difícilmente dejaremos de ser.

Me declaro, sin ninguna culpa, una perdida relativista y de paso los invito a ustedes, mis queridos cómplices lectores, a que vean este escenario vivido a través de los ojos y las palabras de esta humilde narradora. El amor y el odio hacia lo diferente existen como dos caras de un yo. Y este relato pretende mostrarles algunos fragmentos de una idea que ahora dirige mi vida y mi oficio: creo firmemente en que la única alternativa posible frente a la miseria humana radica en la comprensión de la diferencia a través de una vivencia profunda, constante y consciente de la diversidad.

\section{Sonar y escuchar}

(La experiencia de la diversidad a través de la música)

Mis padres cuentan que un día durante el embarazo de mi mamá ella, al tropezarse, se golpeó provocando en mí un tremendo susto. El bebé que era yo, se quedó atemorizado e inmóvil durante un tiempo, el suficiente 
para generar preocupación e incertidumbre. Dice mi papá que yo no respondía a ningún estímulo, ni a su voz, ni a los empujoncitos con los que reclamaban mi atención. Él decidió entonces que había que obligarme a moverme a como diera lugar, para comprobar que seguía con vida. Se le ocurrió entonces la buena idea de poner a sonar la Introducción y Rondó Caprichoso de Camile Saint-Saëns. Pieza que me conmueve desde antes de tener conciencia de mi memoria.

Allí me quedé atenta escuchando y al final de la pieza me regocijé, devolviendo la tranquilidad a mis ya angustiados padres. No sé si la Introducción y Rondó Caprichoso me produce tanta emotividad por lo que algunos llaman estimulación temprana (que en la época en que nací no estaba de moda y de la que mis papás no conocían ni el concepto ni el nombre). O más bien, porque las secuencias de sonidos de esta pieza pertenecen a un universo musical que antecedió a mi conciencia y determinó mi existencia.

He sentido desde siempre una pasión irrefrenable por la música. Nunca he dejado de escuchar, sonar y bailar. Crecí rodeada de discos de músicas variadas. Cuando era niña mi mamá trabajaba en una emisora y tenía acceso a centenares de discos de música de todos los géneros y estilos. Yo escuché cada uno de ellos en el tornamesa de mi casa, y recuerdo de memoria canciones de baladas, tangos, cumbias decembrinas, salsas apasionadas y merengues festivos. Mi frenesí por la música me llevó a cantar en coros, tunas de barrio y escuela, me llevó a tocar tambora en una agrupación de villancicos. Más tarde cuando pude aprender a leer música en partituras y a solfear, descubrí un nuevo lenguaje que se escribía, se leía y al mismo tiempo provocaba el sonido. ¿Qué cosa más maravillosa podía existir? Entendí entonces el poder del silencio en la construcción de la música, y descubrí una forma de sensibilidad de la que jamás me he desprendido.

Mi mejor amigo fue durante un tiempo un violonchelo; por cerca de 15 años toqué sistemáticamente en grupos musicales. Primero en orquestas de infantes irremediablemente desafinados. Fui feliz pulsando los tresillos del Negro Cirilo. Estuve en orquestas juveniles de violines chillones sin vergüenza. Alguna vez soñé con viajar a Italia y hacer música en un gran conservatorio del otro lado del Atlántico. En ese momento no sabía muy bien qué era Italia exactamente, lo único que me gustaba era que estaba lejos y que llegar sería difícil. La música fue para mí el espacio-tiempo de liberación ante la frustrante cotidianidad vivida en el colegio: forzado espacio de conocimiento al que las normas de mi cultura me llevaron a aprender. Aquel espacio hermético en el que el conocimiento 
se acorrala. La vida en el colegio me aburrió casi todos los días y no tengo casi ningún afecto por los 14 años que pasé allí. Las cosas verdaderamente importantes las aprendí en las orquestas, en los grupos musicales, en los talleres de artesanías, en la calle, en el monte y en mi casa, en compañía de libros, discos y humanos que me amaban.

Tuve muchos días de emocionantes aventuras al lado de mis amigos músicos; tuve días de estrés y de amargura cuando me dolió el cuerpo de tanto hacer música. Pero jamás me cansé ni me cansaré de ser el yo musical que fui y que soy. No hay humanidad sin música y lo humano no se puede comprender por fuera de la música. Esta forma particular y única del lenguaje maravilla, entre muchas otras razones, cuando hacemos conciencia de que a la textura del sonido se le llama color. Nombre utilizado en medios musicales en los que se reclama atribuir a un sonido particularidades de otro universo sensorial como sería la percepción de la luz (lo que llaman "sinestesia").

Recuerdo que entendí el poder de la música a través de múltiples situaciones y metáforas de mi experiencia; sé que jamás lograría poner toda esa emotividad en ningún texto escrito. Porque la música me permitió saber desde muy temprano que existían muchos tipos distintos de lenguajes posibles que conjugaban experiencias sensoriales múltiples, creando sentimientos, recuerdos, pulsiones y pensamientos ilimitados. Marcando rutas infinitas en sujetos plurales.

\section{Los libros y los sueños}

(la experiencia de la diversidad a través de la literatura)

Recuerdo los libros como el más seguro de mis refugios infantiles. Mi papá fue el primero en enseñarme el amor a los libros y quien me dio la bella oportunidad de acceder a ellos antes de aprender yo a leer. Escuché, desde que tengo memoria, historias fascinantes contadas por la voz poderosa y versátil de mi padre, quien sabía imitar todo tipo de personajes, desde piratas de mares lejanos, hasta insectos furtivos, ocultos en los árboles de selvas infinitas. Su voz me llevaba por lugares inexplorados y dibujaba en mi imaginación los rostros de personajes, que aún tengo la sensación de conocer bien. Personajes fantásticos de largos cabellos, amantes desolados a quienes su dolor convirtió en cigarras cantoras, damas doradas que cumplían los deseos absurdos de algún animal de patas cortas.

Recuerdo que mi padre tenía un don excepcional como narrador nocturno. Después de mucho haber leído juntos, la poderosa somnolencia 
de niña pequeña se apoderaba de mí, pero mis ansias de saber más sobre la historia en curso me hacían forzar la vigilia. Mi papá me veía cerrar los ojos mientras yo seguía asintiendo como si lo escuchara, entonces él transformaba el curso del relato, hacía que en unas pocas líneas mi personaje favorito sufriera algún tropiezo o fuera objeto de una intempestiva aventura. Allí yo despertaba sobresaltada, en ese pequeño umbral que divide la imaginación onírica y la literaria, lugar en el que nacen las figuras más improbables, tenebrosas y hermosas de la imaginación humana.

Entonces, le decía a mi padre (quien esperaba siempre mi reacción): ¡Eso no es posible! ¿Cómo así que ese pato se quedó con todo el oro? Cuando yo no reaccionaba ante el absurdo o ante algún inesperado desenlace, mi papá sabía que estaba irremediablemente dormida. Luego venían los sueños descabellados que siempre me han caracterizado. Casi siempre he creído que yo he vivido más de una vida. Por un lado, aquella que pasa mientras duermo y, por el otro, aquella que experimento cuando estoy despierta. Tengo en los sueños experiencias tan reales que cuando me despierto siento la firme convicción de haber vivido una suerte de realidad otra. En los sueños he recorrido lugares en donde los personajes de la literatura que mi papá leía para mí y que luego yo leí para mí misma, se transformaban en seres reales que compartían sus experiencias conmigo. En los sueños yo les preguntaba cómo era el mundo del que venían, les pedía que me anticiparan el final de aquellas historias que yo conocía parcialmente. Les pedía que me llevaran con ellos. Algunas veces me llevaron, otras veces me atacaron, me persiguieron, me asesinaron, me volvieron a la vida, me hablaron en lenguas extrañas. Los personajes de las historias que más he amado u odiado me acompañan por años.

Recuerdo el olor de los libros que mi papá compraba a un vendedor que se los llevaba directamente a la puerta de la casa. Era un vendedor de libros de literatura y discos de música instrumental a domicilio, creo que se llamaba Conrado. Recuerdo la visita de aquel hombre cuyo oficio ya no existe. Yo lo esperaba como quien espera la salida triunfal de un mago, que aparece cargado de maravillas insólitas. Don Conrado sacaba de su bolso libros de imágenes saltonas, esos que al abrir y cerrar generan el movimiento de figuras de papel. Al abrir el libro aparecían las fauces de un dinosaurio, el vestido de una princesa, la cabeza de un suricato. El olor de los libros nuevos se adhería entonces a la imagen de las ilustraciones de las portadas. Entre ellas, recuerdo fielmente aquella de las historias de corsarios y bandidos. Luego el hombre armado de pelo rojo saltaba desprendiéndose del papel para terminar sentado a mi lado con su mirada temeraria. 
Recuerdo mi libro favorito en determinada época, durante mi niñez temprana. Yo pedía a mi papá que me lo leyera casi todos los días. Recuerdo algunas anécdotas relativas a este libro por lo que cuentan mis padres y sus amigos. Según ellos alguna vez mientras era aún una niñita de inseguros pasos, le dije a un grupo de adultos que descansaban charlando en la sala de mi hogar: "Miren ¡Yo ya sé leer!" Y abrí el librito en cuestión en la primera página, y con el dedo empecé a recorrer línea por línea recitando el contenido, de manera exacta a como estaba escrito. Los adultos que pocas veces prestan atención a los niños, ese día se quedaron en silencio mientras yo "leía" para ellos. Mi papá entre risas no me dejó avanzar mucho más. Les dijo: es que tiene una memoria auditiva la verraca, ella todavía "no sabe leer". Mi tía respondió aturdida: "¿Esta muchachita es un duende!" Yo era un duende, porque vivía en un lugar encantado lleno de estantes de madera cargados de libros. Vivía en una calle y un barrio, en donde muy probablemente la nuestra sería la única biblioteca. Era un duende porque en las historias, que mi imaginación creaba al compás de los párrafos, yo no pertenecía a este mundo.

Cuando me despertaba en las mañanas les contaba a mis padres mis sueños; ellos me miraban a veces con asombro, otras veces con temor y otras veces con curiosidad. Todos estos sentimientos, están asociados a la experiencia de lo diferente. La literatura fue mi primera puerta a la diversidad cuando no sabía ni qué era ni de qué se trataba. Había nacido en una ciudad donde experiencias de la diversidad cultural eran menos que mínimas: toda la gente la misma, toda la gente el mismo idioma, toda la gente la misma ropa, el mismo acento, el mismo dios. Sin embargo, mi sed por conocer lo diferente me llevó a leer, cuando fui adolescente, las novelas rusas y a los poetas malditos. Cada autor me convencía de su verdad y yo caía obnubilada por un tiempo ante la fuerza de alguna idea que me recorría de arriba abajo de manera irrefrenable. Luego aparecía un nuevo libro, una nueva aventura, una nueva realidad posible.

Mis días favoritos eran aquellos en los que no tenía una hora impuesta para despertarme ni para irme a dormir. Tenía entonces la libertad para leer y dormir a deshoras. Me despertaba y tomaba aún somnolienta el libro del piso, leía hasta que me quedaba dormida leyendo y aparecía en mis sueños una realidad paralela a la literaria. Me despertaba y seguía leyendo y durmiendo en intervalos, separados por las comidas maravillosas preparadas por mi mamá ¡Qué dicha sublime la que me permitió la juventud que viví al lado de mis libros, al lado de aquellas historias que se convertían en melodías que podría rememorar para siempre! 
Fueron la literatura y los sueños los que me hicieron creer en la posibilidad concreta de conocer y descubrir la magnífica y al mismo tiempo tenebrosa diversidad de lo humano. Los relatos sobre pueblos lejanos, sobre idiomas y letras extravagantes, me dejaron creer que algún día yo los conocería allí en cuerpo y alma, compartiría con ellos a la mesa, maravillándome por no entender nada. Las historias sobre el mar, el río, la selva, la nieve y el desierto hicieron posible que yo soñara con estar algún día lejos de las montañas de café y de las calles angostas y empinadas que me aprisionaron por más de 20 años. Una prisión de la que escapaba todos los días por puertas hechas de papel, tinta y polvo.

\section{Caminar, observar y oler}

(la experiencia de la diversidad a través de los lugares)

Ya había visto varias veces el río desde los muelles. El río atraviesa la ciudad tranquilamente, y en ocasiones es difícil descifrar su movimiento para saber hacia qué lado está cayendo. En los muelles el viento sopla con fuerza en los tiempos del frío y las gaviotas vuelan graciosas para luego descender a comer basura. Ese día, los muelles estaban llenos de gaviotas y el viento desperdigaba la basura causándoles una suerte de estado de alerta y diversión. Todas las aves -gaviotas, palomas y algunos pájaros que ya habían regresado o que jamás se habían ido- estaban parados o volando alrededor de los desperdicios y sobre el espléndido río, apacible e implacable. Decidimos caminar esta vez todo el tiempo por el muelle evitando la ruta que seguían los carros, pasando siempre por debajo de los puentes. Grandes puentes de arcos en concreto, puentes de metales diversos. Puentes flacos, altos, gordos, pintados, calados; y nosotros siempre debajo de ellos, caminando sobre el muelle.

Debajo de los puentes había pinturas enormes de artistas desconocidos que decoraban los pasajes oscuros. Nos acompañaba el persistente olor a orines y a hollín, mientras las imponentes pinturas nos abrían el camino. Algunos personajes estaban parados vigilantes, como si simplemente observaran pasar el río, como simplemente esperando que alguno de los barcos zarpara. Se escuchaba el agua, los carros encima. Al fondo, en lo profundo de la cavidad de un arco, un hombre tocaba una gaita escocesa que resonaba a lo largo del muelle con una fuerza que parecía inagotable. Los fuelles de la gaita absorbían y soltaban el aire espeso sin que jamás se detuviera el sonido que emergía, mientras el aire salía y entraba. Una cadencia sonora sin pausa. Debajo de los puentes había pequeñas ciudades de iglús verdes. Los muros de estas ciudades subterráneas estaban pintados de fosforescentes colores, las 
calles eran de piedra y el cielo siempre era gris. Gris porque no puede ser de otro color el cielo de aquellas ciudades debajo de los puentes.

El muelle nos llevó hacia un pequeño túnel que de repente se abrió camino hacia una explanada de concreto en la que se erguían algunos árboles. Luego fueron apareciendo más y más árboles hasta que nos encontramos sumergidos en un bosque. Los bosques en invierno desarman mi idea de bosque. Los troncos grises y el paisaje desierto, el suelo lleno de helechos inmortalizados por el frío. Las rocas recubiertas de un musgo verde. Al tacto, el musgo que uno espera esponjoso y húmedo está irremediablemente seco y rígido. Los árboles centenarios se alzaban por encima de los pequeños cuerpos humanos y el imponente paisaje monótono de árboles sin hojas hacía que no fuera posible imaginar los límites del lugar. Un lugar que podría recorrerse en círculos mil veces sin percibirlo siquiera. En el bosque vivían animales que se escondían y que nunca se dejaban ver. Vi solo las huellas de sus patas en el fango. Luego escuché suaves murmullos callados en los árboles. No se veían los pájaros y tampoco había insectos que de cerca parecieran extraterrestres. Dos mariposas se atravesaron en el camino, evocando tristemente las nubes de colores que se forman en las selvas tropicales. Una era amarilla, la otra era azul con manchas rojas. Eran pequeñas y ordinarias y al mismo tiempo el único ornamento de este bosque espléndido que en mi caminar soñé ver reverdecer.

Los lugares se hacen amar u odiar, así como pasa con algunas personas. Los lugares construyen poco a poco sensaciones diversas que terminan por enamorar y encantar o desenamorar y generar desprecio. Así como sucede con algunas personalidades, cuesta al comienzo lograr afinidad y agrado con los lugares: hay que construir la empatía con esfuerzo, al caminar, al oler y observar sus rutas. La imagen de esta ciudad de edificios monumentales, viejos puentes y parajes de olores agrios, que me costó tanto aprender a querer, ahora me genera una nostalgia particular. Al principio tuve que aprender a soportarla, nada de amor, nada de pasión, nada de empatía. Solo era un coloso vetusto y apático. Y lo fue durante un buen tiempo.

Luego me enamoré profundamente de sus calles y caminos sinuosos, me encantó su ritmo y su carácter. Me fascinaron sus parajes curvos, sus callejones muertos. La aprendí a amar con dificultad y por eso el amor se hizo más fuerte, así como pasa con las personas. Tuve que construir mis propios motivos para quererla y esos motivos se convirtieron en fuertes certezas. Cuando me fui, me dolió dejarla porque había entendido que, como pasa con ciertas personas, cuando las amas sinceramente hay algo 
de ti que se adhiere a ellas y por ese pequeño fragmento quedas y quedarás irremediablemente atada.

Ese vínculo, que se forjó en la dificultad de aceptar, entender y eventualmente amar lo que se presentaba al principio tan distinto y ajeno, continúa fuerte y poderoso. En este caso la aceptación de lo diferente no tiene que ver con la resignación, aun cuando sea un poco así al principio: la aceptación es aquella comprensión auténtica y completa de una realidad otra. Al aceptar dejamos la puerta entreabierta, logramos entender lo que está en juego así no nos convenza. Entre menor sea la experiencia de la diversidad, menor será nuestra capacidad de aceptación. La aceptación se logra enfrentándose a una realidad que representa riesgo, no hay que aceptar lo que ya está y se da por sentado. No hay que aceptar lo que es igual o similar a nuestro universo.

Los lugares que recorrí en cuerpo y alma tras abandonar mi ciudad natal, me dejaron aprender que yo era nimia. Lo entendí al estar en una ciudad rodeada de millones de personas que evitan mirarse, evitan tocarse, evitan hablarse. Una ciudad en la que supe lo que era el anonimato; me sentí abrumada al principio y luego infinitamente feliz. Me di cuenta de que yo no era más que un simple fragmento y que el mundo seguiría allí cuando yo ya no estuviera. La experiencia de la diversidad permite relativizar la magnitud del yo. La importancia que le damos a nuestra propia existencia se transforma cuando reconocemos nuestro pequeño lugar en el universo de lo humano, así como nuestra insignificante materialidad dentro del cosmos. Cuando nos permitimos concebirnos frágiles, intrascendentes, impotentes e irrelevantes, vemos en la realidad de los otros la misma fragilidad y sabemos entonces que estamos hechos de la misma substancia.

\section{El jardín y los animales no humanos}

(La experiencia de la diversidad en la naturaleza)

Acostumbraba a comprar frutas a la salida de las bocas del metro. Casi siempre compraba bananos que en ocasiones resultaban ser colombianos. Una vez me acerqué a comprar, como habitualmente, y me di cuenta de que los bananos tenían pegada una etiqueta de comercio justo. Una etiqueta que se ha vuelto moda en Europa, "label" que muchos reconocen como una prueba de calidad y que generalmente produce una satisfacción moral en el consumidor capitalista del "primer mundo". Los que sabemos un poco de la lamentable mafia creada alrededor de estos certificados no nos encaprichamos mucho que digamos con los productos que portan la etiqueta. Esta vez era claro que las etiquetas habían sido 
despegadas de otro producto y adheridas luego a mis bananos del metro. Me pareció curioso y simpático, no había visto esto antes. Solía pelar uno de los bananos y comerlo camino a casa. Esta vez me di cuenta de que los bananos estaban especialmente insípidos y pálidos (no era extraño que esto ocurriera). Me pregunté de dónde venían, quién los habría cultivado. Pensé en los bananos de mi casa en el Faro. Pensé en los pájaros libres de mi casa en el Faro.

Mientras caminaba recordé las semillas de calabaza que solía comer a lo largo de mis largas jornadas en la biblioteca (me gusta leer y comer semillas); recordé que de las últimas que había comprado en un mercado hindú, algunas sabían a alcanfor y otras cuantas a petróleo. Luego pensé en que debería comprar las semillas en alguno de esos almacenes "bio" que además tienen la famosa etiqueta de comercio justo. Rápidamente pasó por mi mente la idea de que estas últimas serían mejores y seguro no sabrían a alcanfor o a petróleo. Rápido también reí de mi ingenuidad, mientras miraba mi banano pálido, deshojado.

Recordé la docena de manzanas que compramos algún día en el mercado de Ménilmontant. Las recordé rojas y brillantes expuestas en el mercado para luego, en casa, haberles tenido que quitar con la uña aquella detestable y engañosa capa de parafina que les habían puesto para convencernos de que "realmente" eran rojas y brillantes. Recordé la lechuga que por error se quedó dos meses en la nevera y cuando la saqué estaba intacta, verde y húmeda, sin un solo hongo, ni rastro de hoja marchita. Recordé las fresas que al cortarlas nunca olieron a fresa y tampoco mancharon de rosa ni el plato ni la boca.

Mi regla para ir al mercado es siempre desconfiar, siempre pensar que si el melón está barato es porque lo sembraron en los campos radioactivos de Ucrania. Que si el pescado está brillante es porque lo engordaron con hormonas en algún lago de nombre impronunciable. Que si los duraznos están suaves y grandes es probable que adentro ya no tengan ni siquiera el corazón.

Pues bien, creo que es lo mismo que aprendí desde pequeña al otro lado del Atlántico. Debía creer en que si alguien era demasiado gentil, algo querría a cambio. En que si un desconocido se acercaba con cautela quería de seguro robarme. Que si alguien me regalaba un dulce en la calle podría tener burundanga. Que más vale desconfiar y ser precavido, que nadie sabe quién es quién. Por eso me he permitido pensar que el escepticismo se ha convertido, cada vez con más fuerza, en el motor de nuestras acciones cotidianas. Las que se han vuelto en gran medida inconscientes 
y a causa de ello poderosas. Desconfiar y creer que siempre puede haber algo guardado más allá de lo evidente es ser prudente. La prudencia es una virtud. ¿La prudencia que hace verdaderos sabios?

Por todo lo anterior he descubierto que cuanto mayores son la incertidumbre, la duda y la desconfianza, mejores amigas son las plantas que uno mismo cuida. Los ritmos de la naturaleza son implacables y me dan tranquilidad al generarme certezas. El agua hace crecer las hojas y los tallos, el viento dispersa las esporas y el olor de las flores, la tierra se satura y se quiebra con el paso del tiempo. Todo esto sucede casi siempre independientemente de mi voluntad, generando una realidad cierta. Me reconforta sentir el poderoso influjo de todo aquello que se encuentra parcial o totalmente por fuera del poder humano. Por eso he decidido cuidar y ser cuidada por un jardín.

Antes de irme para alguno de mis tantos recientes viajes, me percaté de que dejaría en mi casa alrededor de 50 plantas que necesitarían de atención humana por lo menos una vez por semana. No me había percatado de la cantidad de plantas que vivían conmigo hasta ese día. Ellas y yo nos dedicamos tiempo mutuamente cada día, porque un jardín es una entidad que demanda atención, cuidado y amor. Cada planta tiene sus ritmos para beber y para buscar la luz, algunas se tardan, otras van de prisa, tan de prisa que el movimiento es perceptible a simple vista. Por ejemplo, en mi casa viven conmigo un par de palmeras miniatura que tienen mi edad, las heredé de mi papá y él de su abuela quien fue la que las plantó. A ellas las llamamos "Las Palmitas", nombre poco original, pero a través del cual nos recordamos que necesitan mucha agua y diariamente hay que darles de beber, sobre todo en tiempos de calor.

Mas también vive conmigo una planta enorme, de más de dos metros, robusta de tronco y hojas de un verde encendido, que casi nunca bebe agua y puede estar alejada de la luz. Hay otras de mis plantas que, por el contrario, cuando uno menos se lo espera, se giran para buscar con el copo de sus ramas un rayito de luz que se coló por una hendija. Hay otras que son apetecidas por la gata que las muerde, a veces hasta matarlas. Algunas plantas de mi jardín tienen flores y hojas y otras solamente tienen hojas. Sin embargo, he recibido la bella sorpresa de ver florecer una planta que jamás había dado una flor, y que en general no sabíamos que florecería. El día en que esto sucede o aquel en el que le encuentro a una de mis plantas una nueva hoja, flor, rama o fruto, se produce dentro de mí una pequeña felicidad juguetona. Más o menos es la misma alegría que me da robar 
hijos de plantas en los jardines ajenos (solamente robo en menguante). Viven conmigo muchos hijos robados y hacen entre todos, una colección de verdes cómplices.

En el Faro hay mucha más tierra para dejar vivir plantas y animales, humanos y no humanos. Viven allí plantas salvajes y otras domesticadas. En el corredor del frente de la casa hay más de 20 canastas con helechos, suculentas, bromelias, geranios, novios, orquídeas, plantas peludas con flores rojas, plantas de hojas grasas con flores amarillas. En el frente de la casa, al aire libre, viven plantas caprichosas sembradas en troncos: cuernos de alce y orquídeas zapatico. Otras plantas que crecen y se reproducen con frenesí: filodendros, rayo de luna, cintas, durantas, calateas de todos los colores. Plantas con flores que dan ganas de abrazar como las hortensias azules de mi mamá.

Hay árboles jóvenes, pero ya lo suficientemente altos como para admirarlos desde lejos: los nogales cafeteros, los guamos frondosos y un guadual que ya casi se deja tocar desde el planchón de las hamacas. Todos estos árboles se mecen al ritmo del viento que baja por la cuenca, viento frío entre las montañas que susurra y hace sonar el agua como si estuviera respirando. Llegan a nuestra casa en el Faro pájaros de todos los colores: calandrias, toches, loras, periquitos, siriríes, carpinteros, tángaras, azulejos, colibríes, barranquillos, mirlas, soledades, gavilanes, turpiales y reinitas. Todos magníficos en su gran variedad de colores y tipos, hembras y machos con distintas pintas y tonalidades.

Viven en el Faro varios cuadrúpedos de narices mojadas que nos han dado su compañía en este bello lugar. Algunos ya no están entre nosotros: la Flaca y Tony, que en paz descansen en el cielo de los perros. Cielo en donde hay comidas cárnicas ilimitadas de diferente naturaleza, cómodas camas de ásperos materiales, riachuelos donde bañarse, mortecinas y excrementos donde revolcarse y pastizales infinitos donde correr al perseguir presas reales e irreales. Cielo idílico en donde no viven ni las pulgas, ni las garrapatas, ni las cadenas de los humanos. Los perros que aún viven en el Faro son el Negro y Cabuya. El primero tiene canas en la barba y su fornido y atlético cuerpo lleva con él la marca de batallas campales, triunfos y fracasos perrunos. La segunda tiene la particular característica de llevar el pelo de tres perros distintos en su cuerpo pesado de patas raramente cortas. Un pelo rústico y áspero que inspiró su nombre.

En el Faro también viven gallinas y gallos, que caminan en grupo buscando insectos en el pasto, caminan tongoneando sus colas, cantan en las mañanas la dulce melodía de la felicidad en el rastrojo. Son todos ellos 
animales no humanos que "pertenecen" a humanos vecinos, sin embargo, somos nosotros su mejor refugio y permanecen fieles a nuestro lado todo el tiempo que allí estemos. Ellos son libres animales del campo de los cuales nosotros somos extrañas mascotas. Estos animales capturan mi espíritu humano provocando en mí un amor que los hostiga y los asombra. Quiero siempre tocarlos, cargarlos, besarlos, perseguirlos para que huyan de mi extravagante emotividad. Amo verlos evitar mis brazos alrededor de sus cuellos como desesperados por no entender que esos gestos vengan de un bípedo animal de lenguaje.

Este relato me permite evocar una de las preguntas más antiguas de la antropología, que es justamente aquella que se interroga por el punto de inflexión entre la animalidad pre-humana y los comienzos de la civilización. En los orígenes de la disciplina antropológica a finales del siglo XIX, los científicos evolucionistas se interpelaban por el momento en el que los seres humanos habían sufrido el proceso de complejización social y cultural que les había permitido dar el salto del "salvaje" al "humano". Muchas de las teorías sobre la evolución cultural afirman que los primeros momentos de la complejización social coinciden con el desarrollo del lenguaje especializado y la capacidad de reconocer los grupos parentales, y sobre todo la emergencia de las leyes del incesto. Los evolucionistas afirmaban que las primeras leyes del parentesco ayudaron al hombre a salir de su animalidad y entrar de a poco en el mundo de lo humano.

Así, naturaleza como aquel punto de partida del que el ser humano intenta despojarse por medio del proceso de civilización, se convierte en la antítesis del anthropos: la cordura, la civilidad, el avance y el desarrollo. Necesariamente esta definición de naturaleza es antropocéntrica y no solamente se traduce en todo lo no humano, sino en todo aquello que está al servicio del hombre, todo aquello susceptible de domesticación.

Me permito entonces hablarles ahora de Pinina. Ella se ha convertido en mi tótem: Pinina ¡Cánido líder! No sabemos dónde vive, tampoco sabemos cómo y de dónde llega, ni cómo y hacia dónde se va. Llega como una aparición con su cuerpo ligero. Pinina es la dulce y poderosa conjunción entre un zorro de monte y un perro, animales que por su biología pueden aparearse y procrear. Pinina es roja como un zorro, tiene orejas de zorro altas y puntiagudas, hocico alargado con una fina nariz negra que parece una ciruela pasa. Tiene patas esbeltas y figura grácil, su cola es peluda y frondosa como la de un zorro de monte. Ella está con nosotros casi siempre que estamos en casa, los vecinos dicen: ¿Cómo hace esa perrita para saber cuándo es el fin de semana? Se queda con nosotros aun cuando a veces no quiere comer y no recibe la comida que le 
damos a los otros perros. No come si está llena y a veces recibe algún hueso para luego ir a enterrarlo. Enseguida se acuesta atenta a vigilar el lugar donde aún quedan las huellas de sus ágiles patas al cavar. Pinina es cazadora de animales del monte, es veloz y fuerte. Hace cuevas donde duerme y ama tirarse al sol por largo tiempo para sacarse de encima los molestos parásitos.

Verla me genera una alegría sin igual, haberme encontrado con Pinina ha sido una de las más bellas oportunidades de mi vida. Ese canino, mitad zorro mitad perro, me recuerda siempre la inigualable magia que tiene todo aquello que no se deja domesticar del todo. Me insta a que jamás permita que me domestiquen totalmente y que el animal que vive en mí tiene una sabiduría antigua. Su libertad me da esperanza y me recuerda que la vida se hace andando y que la comodidad no lo es todo. Su indomable espíritu tiene un carácter mágico y sobrenatural, la manera en la que aparece y desaparece, la manera en la que se acerca y luego se aleja de lo humano.

El antropocentrismo es una de las más comunes y poderosas certezas de la mayoría de los Homo sapiens sapiens contemporáneos y en ello radica el fracaso de la condición humana. A mi juicio no hay nada realmente valioso que se pueda aprender por fuera de la experiencia de la diversidad, y esto incluye la diversidad más allá de lo humano. Esa ingenua percepción de la excepcionalidad y centralidad de nuestra especie ha hecho que el conocimiento que producimos, sobre nosotros mismos y sobre todo lo demás, sea aburrido, pobre e insulso. Para curarme, para sanarme de ese mal común he tenido la fortuna de cuidar y ser cuidada por un jardín. He tenido la fortuna de vivir desde que tengo memoria con animales no humanos que me ayudan a entender de dónde viene todo lo que está vivo y hacia donde debemos ir si queremos conservar la vida.

\section{Las veladas y los amigos}

(la experiencia de la diversidad a través de la comida)

En la que ahora es mi casa vivimos tres mujeres. La mayor es una mujer alta de cabellos rizados color marrón intenso. En ocasiones su acento deja escapar sus raíces argelinas que aparecen distantes después de 40 años de no vivir en su país natal. La del medio es una mujer adulta de gafas de marco grueso. Me tardé varios días en cruzarla, vive en casa, pero permanece en el trabajo y solo habla de las cosas que tiene que hacer allí y de cómo su jefe la felicita por hacer la tarea de otros. La menor soy yo, últimamente pálida de rostro. Me he visto llegar con una malla de frutas atrapadas, nostálgicas coloridas del trópico que dejé atrás por un tiempo. 
Una de estas noches nos juntamos por "casualidad" en el salón de la casa. La mayor había recibido a dos de sus mejores amigos. Uno de ellos, el que más fumaba tabaco, había recibido de parte de su madre, directamente desde Argelia, un festín gastronómico. Generosamente lo quiso compartir y por "azar" yo estuve bendecida por su generosidad. El que fumaba menos tabaco es un amigo en común con mi querida Mónica. Él hablaba suavemente y hacía comentarios que reproducían y extendían la amena conversación. Los dos fumadores y mi amiga la mayor tomaban vino blanco. Yo tomaba cerveza. Para ese momento nuestra compañera la del medio, la italiana, no hacía parte del encuentro. Se nos unió cuando la velada ya estaba madura. Había tres botellas de vino y tres de cerveza ya vacías. La invitamos a sentarse y a compartir. Con mi amiga la mayor, dueña de casa, habíamos hablado de cuan extraña se le hacía a ella su compañera la italiana. Me dijo que la creía anoréxica. Varias veces le había propuesto sus manjares argelinos o un chocolate que salía de una caja bella de dulcerías. Todas las veces ella habría aceptado a regañadientes, y habría sostenido en su mano por largo rato el plato con comida o el bombón en mención, para luego abandonarlos disimuladamente. Me dijo además que su despensa dejaba mucho que desear. Las cosas pasaban meses allí sin ser abiertas, luego simplemente envejecían sin remedio.

Ese día la italiana nos acompañó en la mesa en donde reposaban los manjares de una madre enamorada. Había, por una parte, un enrollado perfecto de carne de pollo. El pollo había sido deshuesado cuidadosamente y luego rellenado de carne de cordero molida con especias, entre las que recuerdo algunas y de otras simplemente no conocía ni el nombre. Había comino, cúrcuma, menta, jengibre, canela... En otra fuente se levantaba una piel densa que cubría bajo su manto una mezcla de arroz con especias y carnes de naturaleza inidentificable. La piel estaba bien atada y el corte dejaba ver el relleno mágico. En el plato más pequeño había habichuelas cocidas al vapor. Eran habichuelas del jardín de la madre enamorada.

Comimos hasta la saciedad. Les pedí me explicaran qué era el gran plato de piel atada que me había parecido de un gusto sublime, pero totalmente nuevo en mi repertorio de sabores. En el ritual de la matanza de las cabras, del cual ahora olvido el nombre, se guarda del animal su estómago y sus vísceras. Se deben lavar cuidadosamente hasta obtener una tela blanca, inodora y pulcra que luego es rellenada con las demás vísceras con los perfumes y el arroz.

Después de semejante manjar el postre no podía hacerse esperar. Mis queridos anfitriones desprendieron una a una las perlas húmedas de las granadas frescas que habían comprado en el mercado. 
Granadas dulces y tiernas, de un color fucsia perfecto. Mezclaron los granos con agua de azahar, una pizca de canela y azúcar. Las sirvieron en cuencos transparentes que con la luz de la sala hacían brillar los granos colorados como lámparas de un teatro.

Extasiada de repente recordé que la italiana seguía allí y sentí curiosidad de mirarla. Ella yacía lánguida en su silla bebiendo vino a sorbos, mientras sostenía en su mano un plato blanco casi vacío que contenía tristemente dos o tres habichuelas enfriadas por la desidia. Comió a regañadientes mientras comentaba de vez en cuando alguna anécdota marginal en medio de nuestras conversaciones fascinantes, en medio de esa alegría tan única que dan la buena comida y la buena compañía. Su conducta, su emotividad, su manera de hablar eran tan distintas a todo y a todos los que habitábamos aquella sala. Ella y su personalidad encarnaron por un momento todo lo extraño y lo ajeno, objetivaron la diferencia.

Ese día entendí que la felicidad es un misterio que no se revela sino efímeramente. Y yo solamente puedo preguntarme cómo alguien puede sobrevivir a la miseria del mundo sin los momentos relativamente escasos de dicha que nos proporcionan los sabores, olores y texturas que pasan por boca y nariz al comer. Aquellos momentos en los que comemos en compañía de los que amamos y con quienes sentimos la complicidad ritual de alimentarnos, no por sobrevivir, sino por el magnífico placer que produce. Aquellos instantes en los que bebemos acompañando la comida y sintiendo cómo el alcohol impregna la lengua potenciando el gusto, deteniendo la saciedad, abriendo el apetito, motivando la conversación. Momentos en los que las fronteras entre los individuos se difuminan para construir momentáneamente una masa de sensibilidad y gusto ilimitados. Para aquella mujer italiana probablemente todo esto era trivial, marginal o irrelevante, su manera de interactuar, aquella noche, carecía del contenido y el valor que yo le atribuía a la situación vivida.

Ese día comí platos que jamás me habría permitido, si hubiera permanecido allí atrapada en mi cultura. Cultura paisa que me ha dejado comer durante más de dos décadas fríjoles, arroz y maíz, un día tras otro, sin dejar de sentir que amo comerlos. Ese día hablé en un idioma que no era mi lengua nativa ni la de ninguno de mis amigos y acompañantes. Ese idioma en el que hablamos se convirtió en la única posibilidad de encontrarnos para el disfrute y en cierta medida se convirtió en el medio de expresión privilegiado de nuestra experiencia única compartida. Ese día me permití juzgar a mi compañera la italiana, juzgarla porque no comía, juzgarla porque no tenía ni el más mínimo sentido del humor, juzgarla en silencio sintiendo lástima (uno de los peores sentimientos). 
Esos juicios, que desconocen a priori la naturaleza, el contenido y la experiencia de aquello que se presenta como ajeno, emergen de la incompetencia humana para aceptar y vivir en medio de la diversidad. Ese día me permití amar a mis amigos argelinos, me permití sentir que estaríamos juntos para siempre, aun cuando el tiempo pasara, aun cuando el Atlántico nos separara. Yo los había amado profundamente allí en medio de esa sala de luces tenues, y ese instante de amor es inmortal. No obstante, me permití el capricho del juicio y la apatía, me permití sentir tristeza por aquella mujer que materializó por un momento lo diferente, lo incomprensible y lo lejano.

Ese día, mi triste compañera de casa, la del medio, la italiana, dijo que ella no podía comer carne ni productos lácteos, porque su estómago ya no los digería. Eso la había hecho alejarse de la comida poco a poco y lentamente. La tristeza se había ido sembrando en ella poco a poco y lentamente y eso se podía ver en sus ánimos y en su obsesión por hacer el trabajo de otros. Por la misma naturaleza del momento en el que compartí con ella, supe entenderla y abrazarla en su dolor, supe que no era del todo culpa suya su amargura. La tristeza es un estado estomacal y se cura solamente a través de cautivantes sustancias que le coquetean al placer, llaman la sensibilidad, auguran la pasión y construyen el amor. De esto se trata, de alguna manera, la antropología: observar con atención el lugar que el otro ocupa en aquella infinita y compleja trama de relaciones y emociones humanas (y no humanas). Intentar imaginar y, ¿por qué no?, develar lo que está en juego, para acercarnos a aquello que resulta diferente sin pretender que se transforme a nuestro favor.

\section{Coda}

Las ideas importantes toman tiempo en concretarse y, sobre todo, las ideas importantes nacen de la experiencia profunda de la diversidad. Las infinitas posibilidades de lo humano están más allá de los confines del yo hermético, del sedentarismo, del terco antropocentrismo y de la frustrante estabilidad. La antropología me ha dado la oportunidad de viajar de todas las formas posibles, me ha hecho un ser humano fuerte en la conciencia de mi fragilidad. Ahora entiendo que la antropología nunca fue solamente mi oficio, cuando me veo en retrospectiva me doy cuenta de que difícilmente pude haber sido otra cosa. Soy en mi complejidad lo que soy gracias a la antropología e iré más lejos, sin correr ni detenerme, porque el pensamiento antropológico es inagotable. Esta manera de pensar, este lenguaje que aprendí es mi más genuina manera de acompañar a otros en la vida. 
El camino hacia esta concepción de la antropología ha tenido todos los matices. En ocasiones ha sido doloroso y extenuante. He dado con profesores y colegas prepotentes, maltratadores y extremadamente confiados en sí mismos. He tenido que luchar contra otros que enseñan la antropología sin jamás ejercerla, carentes de pasión y de refinamiento. No obstante, me he encontrado con maestros inigualables que me han permitido cultivar lo que soy. Plantas, animales humanos y no humanos que han sido mis maestros, porque los maestros existen en todas las formas posibles. Personas que me han enseñado a amar mi oficio en el rigor, a amar la escritura escribiendo, a conocer el mundo viajando (a pie, en bicicleta, en patineta, en carro, en bus, en avión, en tren, en panga, en tranvía, en Willis, en chalupa, en burro, en los libros). Animales no humanos que me han enseñado el valor de la libertad, el poder de lo salvaje y las consecuencias de la tenacidad. Plantas que me han enseñado la complejidad del paso del tiempo y la fortaleza que les permite a sus raíces romper la roca. 